\title{
Effect of Hot Water Blanching Treatment on Quality of Dried Potato Slices
}

\author{
D.C. Kapadiya $^{1 *}$, J.M. Makavana ${ }^{2}$ and M.K. Kathiria ${ }^{3}$ \\ ${ }^{1}$ Department of Farm Machinery and Power Engineering, CAET, JAU, \\ Junagadh, Gujarat, India \\ ${ }^{2}$ Department of Renewable Energy Engineering, CAET, JAU, Junagadh, Gujarat, India \\ ${ }^{3}$ School of Science, Engineering and Technology, Durham College, 2000 Simcoe Street North, \\ Oshawa, Ontario, Canada \\ *Corresponding author
}

\section{A B S T R A C T}

\begin{tabular}{|c|c|}
\hline Keywords & The potato is a starchy, tuberous crop from the perennial nightshade Solanum tuberosum. \\
\hline $\begin{array}{l}\text { Hot Water } \\
\text { Blanching } \\
\text { Treatment, Dried } \\
\text { Potato Slices }\end{array}$ & $\begin{array}{l}\text { Potato has high level moisture content, hence it is perishable crop. Blanching is an unit } \\
\text { operation prior to freezing, canning, drying in which fruit and vegetables are heated for the } \\
\text { purpose of inactivate enzymes; modifying texture; preserving colour, flavour and } \\
\text { nutritional value; and removing trapped air. An experiment was conducted to evaluate the }\end{array}$ \\
\hline Article Info & $\begin{array}{l}\text { effect of pre-treatments on quality of dried potato slices. Potato slices ware subjected to } \\
\text { various pre-drying treatment viz., blanching in hot water at temperature, i.e., } 60,70,80,90\end{array}$ \\
\hline $\begin{array}{l}\text { Accepted: } \\
\text { 20 June } 2018 \\
\text { Available Online: } \\
10 \text { July } 2018\end{array}$ & $\begin{array}{l}\text { and } 100^{\circ} \mathrm{C} \text { and blanching time, i.e., } 2.0,3.0,4.0 \text { and } 5.0 \text { min. Based on the above study, it } \\
\text { may be concluded that treatment } \mathrm{B} 5\left(70^{\circ} \mathrm{C} \text { temperature }+2.0 \text { min. blanching time) was }\right. \\
\text { found to be best among all the treatment with optimum recovery of potato slice, shrinkage } \\
\text { percentage, rehydration ratio, reducing sugar, sucrose and total phenol. }\end{array}$ \\
\hline
\end{tabular}

\section{Introduction}

The potato is a starchy, tuberous crop from the perennial nightshade Solanum tuberosum. The word "potato" may refer either to the plant itself or to the edible tuber. It is the world's fourth largest food crop, following maize, wheat and rice. According to FAO (2008), Potato is consumed by more than one billion people in the world. It has since spread around the world and become a staple crop in many countries. It is grown in more than 100 countries. Potato has high level moisture content, hence it is perishable crop. Major potato producing states are Uttar Pradesh, West Bengal, Bihar, Madhya Pradesh, Gujarat, Assam, Haryana, Jharkhand and Chhattisgarh. The main varieties of potato grown in Gujarat are Kufri Sindhuri, Kufri Chandramukhi, Kufri Jyoti, Kufri Badshah, Kufri Jawahar, Kufri Pukhraj, Kufri Lalima and Kufri Lauvkar. Potatoes are ready to harvest in June-July. The average world farm yield for potato was 17.4 tonne/ha, in 2013-14 and 45.3 million metric tonne potatoes were produced in India (Anon., 2014 a). 
Potato can be boiled and mashed or baked. It is used in preparing candied yams and pie fillings. It is used industrially as a source of starch, glucose, syrup and alcohol (Ihekowuye and Nguddy, 1995). Nutritive value of potatoes is starch $(15.44 \mathrm{~g} / 100 \mathrm{~g})$, carbohydrates $(17.47 \mathrm{~g} / 100 \mathrm{~g})$, proteins (2 $\mathrm{g} / 100 \mathrm{~g})$, fat $(0.1 \mathrm{~g} / 100 \mathrm{~g})$, minerals $(520.22$ $\mathrm{mg} / 100 \mathrm{~g})$, vitamins $(23.36 \mathrm{mg} / 100 \mathrm{~g})$ and water. In potatoes, such minerals like calcium, copper, iron, magnesium, phosphorus, sodium etc. are present and it contains vitamin $\mathrm{B}_{1}$ $(0.08 \mathrm{mg} / 100 \mathrm{~g})$, vitamin $\mathrm{B}_{2}(0.03 \mathrm{mg} / 100 \mathrm{~g})$, vitamin $B_{3}(1.05 \mathrm{mg} / 100 \mathrm{~g})$, vitamin $\mathrm{B}_{5}(0.296$ $\mathrm{mg} / 100 \mathrm{~g})$, vitamin $\mathrm{B}_{6} \quad(0.295 \mathrm{mg} / 100 \mathrm{~g})$, vitamin $\mathrm{B}_{9}(16 \mu \mathrm{g} / 100 \mathrm{~g})$, vitamin $\mathrm{C}$ (19.7 $\mathrm{g} / 100 \mathrm{~g})$, vitamin $\mathrm{E}(0.01 \mathrm{~g} / 100 \mathrm{~g})$, vitamin $\mathrm{K}$ $(1.9 \mu \mathrm{g} / 100 \mathrm{~g})$ (Anon., $2014 \mathrm{c}$ ).

Blanching is an unit operation prior to freezing, canning, drying in which fruit and vegetables are heated for the purpose of inactivate enzymes; modifying texture; preserving colour, flavour and nutritional value; and removing trapped air. Hot water and steam are the most commonly used heating media for blanching in industry, but microwave and hot gas blanching have also been studied. Different hot water and steam blancher have been designed to improve product quality, increase yield and facilitate processing of product with different thermal properties and geometries.

For most processed fruits and vegetables, blanching is essential to inactive the enzymes responsible for quality deterioration of fruits and vegetables in storage. Blanching is an important heat process in preparation of vegetables and fruits before dehydration and packaging. Blanching is done to inactive enzymes and to destroy the peroxides. Blanching is the process of heating the food rapidly to a predetermined temperature, holding it at that temperature for a definite period and then either cooling a material or passing it to be subsequent processing without delay. Water blanching is performed in hot water at temperatures ranging typically from $60^{\circ} \mathrm{C}$ to $100^{\circ} \mathrm{C}$. However, low temperature long time (LTLT) blanching and combinations of LTLT with high temperature short time (HTST) blanching have also been studied (Rehman and Perera, 1999; Stanley et al., 1995 and Lin and Schyvens, 1995). Water blanching usually results in a more uniform treatment, allowing processing at lower temperatures.

Presently, traditional sun drying is the most common method for drying of potato (Solanum tuberosum) in India. But this traditional method produces the final products of inferior quality. Also, traditional sun drying method has some of the disadvantages like, time consuming, weather dependent, poor quality of the final product and product will lose their glossiness due to direct exposing under the sun rays. .

Microbial spoilage of food products is also controlled by using chemical preservatives which do not include salt, sugar, acetic acid, oils, alcohols, etc., but only microbial antagonists. The inhibitory action of preservatives is due to their interfering with the mechanism of cell division, permeability of cell membrane and activity of enzymes. Potassium meta bisulphite $\left(\mathrm{K}_{2} \mathrm{O}_{2} \mathrm{SO}_{2}\right.$ or $\mathrm{K}_{2} \mathrm{~S}_{2} \mathrm{OS}$ ) is commonly used as a stable source of sulphur dioxide. Being a solid, it is easier to use than liquid or gaseous sulphur dioxide. It is fairly stable in neutral or alkaline media but decomposed by weak acids like carbonic, citric, tartaric and malic acids.

For these reasons, it is desirable to keep blanching treatment conditions at a level strictly sufficient to cause inactivation of the deleterious enzymes, to minimize quality losses. Nutritionally for the better retention of nutrient and water soluble vitamin $\mathrm{C}$ during 
hot water blanching treatment is governed by hot water blanching condition, i.e. temperature and time of blanching. Optimum levels of blanching condition are necessary to get better retention of these nutrients. Keeping these points in view present study was under taken to develop a value added product of potato in the form of slices and to study the effect of pre-treatments (blanching) and drying method on quality of dried potato slice with following objectives.

\section{Materials and Methods}

\section{Raw material}

The potato variety (Kufri Pukhraj) mostly grown in this area was selected for the experiment. Healthy and undamaged tubers which are of uniform size were procured from Sardar Vallabhbhai Patel market, Dolatpara, Junagadh. The potatoes were washed with distilled water and air dried at room temperature $\left(31 \pm 1^{\circ} \mathrm{C}\right)$. An experiment was conducted to prepare dried potato slices at the Department of Processing and Food Engineering, College of Agricultural Engineering \& Technology, Junagadh Agricultural University, Junagadh.

\section{Drying process}

\section{Grading, sorting and washing}

The potatoes were graded on basis of size to maintain homogenity. The diseased, bruished and discolored fruits were separated out and these selected potatoes were thoroughly washed with clean water to remove dirt, dust and fungicidal residues.

\section{Peeling and slicing}

The washed and graded potatoes were peeled with sharp edged knife. Uniform thicknesses of slices were maintained by manual slicing, uneven shaped as well as non-uniform slices were removed carefully (Fig. 1).

\section{Preparation of potassium metabisulphite (KMS) solution}

The potato slice was pre-treated with $0.5 \%$ potassium metabisulphite (KMS) solution to prevent any microbial activity and discoloration of potato slices during drying. The $0.1 \%$ potassium metabisulphite (KMS) solution prepared by dissolving $1.0 \mathrm{~g}$ potassium metabisulphite (KMS) in 1 litre distilled water.

\section{Pre-treatments (Blanching)}

The $100 \mathrm{~g}$ potato slices were socked in $500 \mathrm{ml}$ $0.1 \%$ potassium metabisulphite (KMS) solution in glass beaker. The beaker containing slices with potassium metabisulphite (KMS) solution boiled using heating mental at different treatment combination. To prevent any excess cooking, slicing were taken out and dipped immediately in cold water at temperature of $27^{\circ} \mathrm{C} \pm 2$ for 3 $\min$.

\section{Drying}

The potato slices were loaded uniformly on aluminum trays. The trays were then kept in hot air tray dryer at $60 \pm 2{ }^{\circ} \mathrm{C}$ and $1 \mathrm{~m} / \mathrm{s}$ air velocity for drying. The trays were changed in rotation from lower shelf to upper one to ensure uniform drying. Drying was carried out until constant weight was achieved. Weights before and after drying were measured.

\section{Statistical analysis}

The observations taken for various treatment combinations for dried potato slice were subjected to analysis of variance technique considering two factors Completely Randomized Design with three replications at 
5 per cent level of significance as suggested by Panse and Sukhatme (1985).

\section{Results and Discussion}

\section{Quality evaluation of fresh potato}

The quality of fresh potato (Cv.Kufri Pukhraj) was determined on the basis of biochemical parameters, viz., moisture content, reducing sugar, sucrose and total phenol. The moisture content, reducing sugar, sucrose and total phenol were measured by Ranganna (2000), Miller (1972), Hedge and Hofreiter (1962) and Malick and Singh (1980) respectively (Table 1 and 2).

\section{Quality evaluation of dried potato slice}

The quality of dried potato slice (Cv. Kufri Pukhraj) was determined on the basis of physical parameters, i.e. recovery of dried potato slice, shrinkage (\%) and rehydration ratio. The recovery of dried potato slice, shrinkage (\%) and rehydration ratio were measured by standard formula given as following.

Recovery, $\%=\frac{\text { Weight of dried potato slices }}{\text { Weight of potato slices }} \times 1$ Shrinkage, $\%=\frac{\text { Initial volume }- \text { Final volume }}{\text { Initial volume }} \times$ $\times 1$ Betur

Rehydration ratio $=\frac{\text { Weight after rehydration }}{\text { Weight of dehydrated sample }}$ ehydration ratio of dried potato slices

The quality evaluation of dried potato slice was carried out on the basis of various biochemical parameters, viz., moisture content, reducing sugar, sucrose and total phenol and physical parameters, i.e. recovery of dried potato slice, shrinkage (\%) and rehydration ratio. The mean values of physical and biochemical parameters are reported in Appendix A. (t) were found significant whereas, interaction
Between Tx $t$ was also found significant (Table 3).

\section{Recovery of dried potato slices}

Maximum recovery of dried potato slice was found $(24.18 \%)$ in treatment $\mathrm{B}_{5}$, i.e., $70{ }^{\circ} \mathrm{C}$ temperature and $3.0 \mathrm{~min}$. blanching time (Appendix A). While minimum recovery of dried potato slice were found $(17.35 \%)$ in $\mathrm{B}_{16}$, i.e., $90{ }^{\circ} \mathrm{C}$ temperature and $5.0 \mathrm{~min}$. blanching time (Appendix A). The maximum recovery in treatment $\mathrm{B}_{5}$ may be due to minimum leaching of solid at $70{ }^{\circ} \mathrm{C}$ temperature for $3.0 \mathrm{~min}$ blanching time. Statistically individual effect of temperature $(\mathrm{T})$ and blanching time $(\mathrm{t})$ were found significant whereas, interaction between Tx $t$ was also found significant (Table 3 ).

\section{Shrinkage percentage of dried potato slices}

Maximum shrinkage percentage of dried potato slice were found $(61.41 \%)$ in treatment $\mathrm{B}_{19}$, i.e., $90{ }^{\circ} \mathrm{C}$ temperature and $4.0 \mathrm{~min}$. blanching time (Appendix A). While minimum shrinkage percentage of dried potato slice were found $(27.90 \%)$ in $\mathrm{B}_{3}$, i.e., $60{ }^{\circ} \mathrm{C}$ temperature and $4.0 \mathrm{~min}$. blanching time (Appendix A). The maximum recovery in treatment $\mathrm{B}_{19}$ may be due to minimum leaching of solid at $90{ }^{\circ} \mathrm{C}$ temperature for 4.0 min blanching time. Statistically individual effect of temperature (T) and blanching time

Maximum rehydration ratio of dried potato slice was found (19.13) in treatment $B_{15}$, i.e., $90{ }^{\circ} \mathrm{C}$ temperature and $3.0 \mathrm{~min}$. blanching time (Appendix A). While minimum rehydration ratio of dried potato slice were found (15.31) in $\mathrm{B}_{14}$, i.e., $90{ }^{\circ} \mathrm{C}$ temperature and $2.0 \mathrm{~min}$. blanching time (Appendix A). The maximum rehydration ratio in treatment $\mathrm{B}_{15}$ may be due to minimum leaching of solid at $90{ }^{\circ} \mathrm{C}$ 
temperature for $3.0 \mathrm{~min}$ blanching time. Statistically individual effect of temperature $(\mathrm{T})$ and blanching time ( $\mathrm{t})$ were found significant whereas, interaction between $\mathrm{T} \times \mathrm{t}$ was also found significant (Table 3).

\section{Reducing sugar in dried potato slices}

Maximum reducing sugar of dried potato slice was found $(11.21 \mathrm{mg} / \mathrm{g})$ in treatment $\mathrm{B}_{5}$, i.e., $70{ }^{\circ} \mathrm{C}$ temperature and $3.0 \mathrm{~min}$. blanching time (Appendix A). While minimum reducing sugar of dried potato slice were found (1.8 $\mathrm{mg} / \mathrm{g}$ ) in $\mathrm{B}_{20}$, i.e., $100{ }^{\circ} \mathrm{C}$ temperature and 5.0 min blanching time (Appendix A. The maximum reducing sugar in treatment $B_{5}$ may be due to minimum leaching of sugar at lower temperature and leaching losses at $70{ }^{\circ} \mathrm{C}$ temperature for $3.0 \mathrm{~min}$. blanching time. Statistically individual effect of temperature $(\mathrm{T})$ and blanching time ( $\mathrm{t}$ ) were found significant whereas, interaction between $\mathrm{T} \times \mathrm{t}$ was also found significant (Table 3).

\section{Sucrose in dried potato slices}

Maximum sucrose of dried potato slice were found $(8.01 \mathrm{mg} / \mathrm{g})$ in treatment $\mathrm{B}_{6}$, i.e., $70^{\circ} \mathrm{C}$ temperature and $3.0 \mathrm{~min}$. blanching time (Appendix A). While minimum sucrose of dried potato slice were found minimum (2.91 $\mathrm{mg} / \mathrm{g}$ ) in $\mathrm{B}_{20}$, i.e., $100{ }^{\circ} \mathrm{C}$ temperature and 5.0 min. blanching time (Appendix A. The maximum sucrose in treatment $B_{6}$ may be due to minimum sucrose at lower temperature and leaching losses at $70{ }^{\circ} \mathrm{C}$ temperature for 3.0 min. blanching time. Statistically individual effect of temperature (T) and blanching time (t) were found significant whereas, interaction between $\mathrm{T} \times \mathrm{t}$ was also found significant (Table 3).

Table.1 Treatment combination for potato

\begin{tabular}{|c|c|c|}
\hline Sr.No. & Treatments & Combinations \\
\hline 1 & $\mathrm{~B} 1\left(\mathrm{~T}_{1} \mathrm{t}_{1}\right)$ & $60^{\circ} \mathrm{C}+2 \min$ (time of blanching) \\
\hline 2 & $\mathrm{~B} 2\left(\mathrm{~T}_{1} \mathrm{t}_{2}\right)$ & $60^{\circ} \mathrm{C}+3 \mathrm{~min}$ (time of blanching) \\
\hline 3 & $\mathrm{~B} 3\left(\mathrm{~T}_{1} \mathrm{t}_{3}\right)$ & $60^{\circ} \mathrm{C}+4 \mathrm{~min}$ (time of blanching) \\
\hline 4 & $\mathrm{~B} 4\left(\mathrm{~T}_{1} \mathrm{t}_{4}\right)$ & $60^{\circ} \mathrm{C}+5 \mathrm{~min}$ (time of blanching) \\
\hline 5 & $\mathrm{~B} 5\left(\mathrm{~T}_{2} \mathrm{t}_{1}\right)$ & $70^{\circ} \mathrm{C}+2 \min$ (time of blanching) \\
\hline 6 & $\mathrm{~B} 6\left(\mathrm{~T}_{2} \mathrm{t}_{2}\right)$ & $70^{\circ} \mathrm{C}+3 \mathrm{~min}$ (time of blanching) \\
\hline 7 & $\mathrm{~B} 7\left(\mathrm{~T}_{2} \mathrm{t}_{3}\right)$ & $70^{\circ} \mathrm{C}+4 \mathrm{~min}$ (time of blanching) \\
\hline 8 & $\mathrm{~B} 8\left(\mathrm{~T}_{2} \mathrm{t}_{4}\right)$ & $70^{\circ} \mathrm{C}+5 \mathrm{~min}$ (time of blanching) \\
\hline 9 & $\mathrm{~B} 9\left(\mathrm{~T}_{3} \mathrm{t}_{1}\right)$ & $80^{\circ} \mathrm{C}+2 \mathrm{~min}$ (time of blanching) \\
\hline 10 & $\mathrm{~B} 10\left(\mathrm{~T}_{3} \mathrm{t}_{2}\right)$ & $80^{\circ} \mathrm{C}+3 \mathrm{~min}$ (time of blanching) \\
\hline 11 & $\mathrm{~B} 11\left(\mathrm{~T}_{3} \mathrm{t}_{3}\right)$ & $80^{\circ} \mathrm{C}+4 \mathrm{~min}$ (time of blanching) \\
\hline 12 & $\mathrm{~B} 12\left(\mathrm{~T}_{3} \mathrm{t}_{4}\right)$ & $80^{\circ} \mathrm{C}+5 \mathrm{~min}$ (time of blanching) \\
\hline 13 & $\mathrm{~B} 13\left(\mathrm{~T}_{4} \mathrm{t}_{1}\right)$ & $90^{\circ} \mathrm{C}+2 \mathrm{~min}$ (time of blanching) \\
\hline 14 & $\mathrm{~B} 14\left(\mathrm{~T}_{4} \mathrm{t}_{2}\right)$ & $90^{\circ} \mathrm{C}+3 \mathrm{~min}$ (time of blanching) \\
\hline 15 & $\mathrm{~B} 15\left(\mathrm{~T}_{4} \mathrm{t}_{3}\right)$ & $90^{\circ} \mathrm{C}+4 \mathrm{~min}$ (time of blanching) \\
\hline 16 & $\mathrm{~B} 16\left(\mathrm{~T}_{4} \mathrm{t}_{4}\right)$ & $90^{\circ} \mathrm{C}+5 \mathrm{~min}$ (time of blanching) \\
\hline 17 & $\mathrm{~B} 17\left(\mathrm{~T}_{5} \mathrm{t}_{1}\right)$ & $100^{\circ} \mathrm{C}+2 \mathrm{~min}$ (time of blanching) \\
\hline 18 & $\mathrm{~B} 18\left(\mathrm{~T}_{5} \mathrm{t}_{2}\right)$ & $100^{\circ} \mathrm{C}+3 \min$ (time of blanching) \\
\hline 19 & $\mathrm{~B} 19\left(\mathrm{~T}_{5} \mathrm{t}_{3}\right)$ & $100^{\circ} \mathrm{C}+4 \mathrm{~min}$ (time of blanching) \\
\hline 20 & $\mathrm{~B} 20\left(\mathrm{~T}_{5} \mathrm{t}_{4}\right)$ & $100^{\circ} \mathrm{C}+5 \mathrm{~min}$ (time of blanching) \\
\hline
\end{tabular}


Table.2 Biochemical parameters of fresh potato

\begin{tabular}{|c|c|c|c|c|}
\hline Sr. No. & $\begin{array}{c}\text { Moisture } \\
\text { content } \\
\%(w . b)\end{array}$ & $\begin{array}{c}\text { Reducing } \\
\text { sugar } \\
(\mathrm{mg} / \mathrm{g})\end{array}$ & $\begin{array}{c}\text { Sucrose } \\
(\mathrm{mg} / \mathrm{g})\end{array}$ & $\begin{array}{c}\text { Total } \\
\text { phenol } \\
(\mathrm{mg} / \mathrm{g})\end{array}$ \\
\hline $\mathbf{1}$ & 76.80 & 9.46 & 8.42 & 1.80 \\
\hline $\mathbf{2}$ & 80.18 & 14.21 & 10.26 & 1.67 \\
\hline $\mathbf{3}$ & 80.00 & 12.79 & 12.79 & 2.49 \\
\hline $\mathbf{4}$ & 79.82 & 10.76 & 9.82 & 1.91 \\
\hline $\mathbf{5}$ & 78.82 & 9.89 & 11.49 & 1.76 \\
\hline Mean & 79.12 & 11.42 & 10.556 & 1.92 \\
\hline SD & \pm 1.25 & \pm 1.80 & \pm 1.48 & \pm 0.29 \\
\hline
\end{tabular}

Table.3 Effect of different temperature and blanching time on physical and biochemical characteristics of dried potato slice

\begin{tabular}{|c|c|c|c|c|c|c|}
\hline Treatment & $\begin{array}{c}\text { Recovery } \\
(\%)\end{array}$ & $\begin{array}{c}\text { Shrinkage } \\
(\%)\end{array}$ & $\begin{array}{c}\text { Rehydration } \\
\text { Ratio }\end{array}$ & $\begin{array}{l}\text { Reducing } \\
\text { sugar } \\
(\mathrm{mg} / \mathrm{g})\end{array}$ & $\begin{array}{c}\text { Sucrose } \\
(\mathrm{mg} / \mathrm{g})\end{array}$ & $\begin{array}{l}\text { Total } \\
\text { phenol } \\
(\mathrm{mg} / \mathrm{g})\end{array}$ \\
\hline \multicolumn{7}{|c|}{ Temperature (T) } \\
\hline $\mathbf{T}_{1}$ & 21.740 & 31.193 & 16.848 & 8.264 & 6.838 & 2.188 \\
\hline $\mathbf{T}_{2}$ & 22.028 & 37.673 & 16.458 & 8.088 & 6.727 & 1.291 \\
\hline $\mathbf{T}_{3}$ & 21.099 & 39.467 & 16.490 & 6.763 & 5.951 & 1.226 \\
\hline $\mathbf{T}_{4}$ & 19.455 & 39.038 & 16.857 & 6.460 & 5.112 & 1.011 \\
\hline $\mathbf{T}_{5}$ & 20.954 & 50.147 & 17.122 & 6.178 & 4.795 & 0.919 \\
\hline S.Em. \pm & 0.0973 & 0.0539 & 0.0550 & 0.0954 & 0.0902 & 0.0637 \\
\hline C.D. at $5 \%$ & 0.2781 & 0.1541 & 0.1572 & 0.2725 & 0.2577 & 0.1821 \\
\hline \multicolumn{7}{|c|}{ Time (t) } \\
\hline $\mathbf{t}_{1}$ & 21.851 & 38.681 & 16.915 & 10.649 & 7.088 & 1.309 \\
\hline$t_{2}$ & 19.971 & 33.797 & 16.413 & 8.900 & 6.502 & 1.188 \\
\hline $\mathbf{t}_{3}$ & 20.991 & 43.157 & 16.770 & 5.387 & 5.403 & 1.093 \\
\hline$t_{4}$ & 20.609 & 42.377 & 16.921 & 2.866 & 3.795 & 0.917 \\
\hline 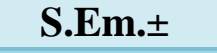 & 0.0870 & 0.0482 & 0.0492 & 0.0853 & 0.0807 & 0.570 \\
\hline C.D. at 5\% & 0.2488 & 0.1379 & 0.1406 & 0.2438 & 0.2305 & 0.1629 \\
\hline \multicolumn{7}{|c|}{$\mathrm{T} \times \mathrm{t}$} \\
\hline S.Em. \pm & 0.1946 & 0.1079 & 0.1100 & 0.1907 & 0.1804 & 0.1274 \\
\hline C.D. at $5 \%$ & 0.5563 & 0.3083 & 0.3144 & 0.5450 & 0.5155 & NS \\
\hline C.V.\% & 1.62 & 0.47 & 0.14 & 4.75 & 5.50 & 19.58 \\
\hline
\end{tabular}


Fig.1 Process flow chart for preparation of dried potato slice

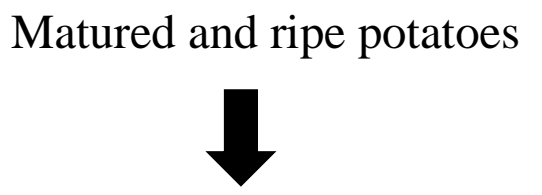

Washing and sorting

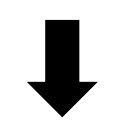

Peeling and slicing

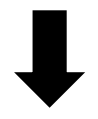

Weighing (100 gm.)

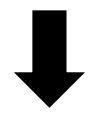

Blanching in $0.1 \%$ potassium metabisulphite

(At different temperatures, i.e., $60,70,80,90$ and $100^{\circ} \mathrm{C}$

For different time, i.e., 2, 3, 4 and 5 minutes)

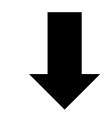

Tray drying

(Temp. $60 \pm 2^{\circ} \mathrm{C}$, air flow $1 \mathrm{~m} / \mathrm{s}$ )

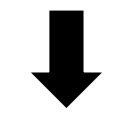

Dried slices

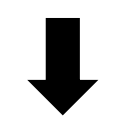

Quality evaluation of prepared slices 


\section{Total phenol in dried potato slices}

Maximum total phenol of dried potato slice was found $(1.58 \mathrm{mg} / \mathrm{g})$ in treatment $B_{5}$, i.e., 70 ${ }^{\circ} \mathrm{C}$ temperature and 3.0 min blanching time (Appendix A). While minimum total phenol of dried potato slice were found minimum $(0.85 \mathrm{mg} / \mathrm{g})$ in $\mathrm{B}_{7}$, i.e., $100{ }^{\circ} \mathrm{C}$ temperature and 5.0 min blanching time(Appendix A). The maximum total phenol in treatment $\mathrm{B}_{5}$ may be due to minimum losses at lower temperature and leaching of phenol at $70{ }^{\circ} \mathrm{C}$ temperature for $3.0 \mathrm{~min}$ blanching time. Statistically individual effect of temperature $(\mathrm{T})$ and blanching time ( $\mathrm{t}$ ) were found significant whereas, interaction between $\mathrm{T} \times \mathrm{t}$ was found non- significant (Table 3).

\section{Sensory characteristics of dried potato slice}

The sensory evaluation of dried potato slice was carried out on the basis of various organoleptic parameters, viz., colour, odour, taste and texture.

The mean values sensory characteristics are reported in Appendix B. The sensory characteristics of blanched and dried potato slices of all the treatment as per the method suggested by Ranganna (2000).

Highest sensory score considering to colour, odour, taste and texture of dried potato slice were found in treatment $\mathrm{B}_{11}, \quad\left(80{ }^{\circ} \mathrm{C}\right.$ temperature and 4.0 min blanching time) i.e., 9.0. The lowest sensory score were found in treatment $\mathrm{B}_{8}\left(70{ }^{\circ} \mathrm{C}\right.$ temperature and $5.0 \mathrm{~min}$ blanching time) (Appendix B).

In conclusion, physical parameter, viz., recovery of dried potato slice decreases with the increases of temperature and blanching time. While shrinkage percentage and rehydration ratio of dried potato slice decreases with the increases of temperature and blanching time. Biochemical parameters, viz., reducing sugar of dried potato slice increases with the increases of temperature and blanching time. While sucrose of dried potato slice decreases with the increases of temperature and blanching time. The sensory evaluation of dried potato slice was carried out on the basis of various organoleptic parameters, viz., colour, odour, taste and texture. Based on the above study, it may be concluded that treatment $\mathrm{B}_{11}, \quad\left(80^{\circ} \mathrm{C}\right.$ temperature and 4.0 min blanching time) was found to be best among all the treatments with optimum recovery of potato slice, reducing sugar, sucrose, total phenol and better sensory score.

\section{References}

Annonymous. (2014 c). USDA Nutrient Database. Source: (http://ndb.nal.usda. gov/ndb.)

Anonymous. (2014 a). Potato varieties.pdf. Central Potato Research Institute, Shimla.

blanching effects of chemistry, Firmness and structure of canned green beans and carrots. Journal of food science. 60:327-333.

Ihekowuye and Nguddy (1995). Effect of pre-treatment on drying rates and drying time of

Latapi, G. and Barrett, D. M. (2006). Influence of pre-drying treatments on quality and safety of sun-dried tomatoes. Part II. Effects of storage on nutritional and sensory quality of sundried tomatoes pre-treated with sulphur, sodium meta-bisulphite, or salt. Journal of food Science. 71(1).

Panse, V.G. and Sukhatme, P.V. (1967). Statistical methods for agricultural workers. Indian Council of Agricultural Research, New Delhi.Journal of Food Technology. 3(3): 361-364.

Rahman, M. S. and Perera, C.O. (1999). 
Drying and food preservation. Handbook of Food

Ranganna, S. (2000). Handbook of analysis and quality control for fruit and vegetable products. Tata McGraw Hill Pub. Co. Ltd., New Delhi.

Rodriguez-Saona, L. and Wrolstad, R. (1997). Influence of potato composition on chip color quality. Am. Potato J., 74: 87-106.

Sahin, F. H., Aktas, T., Orak, H. and Ulger, P. (2011). Influence of pre-treatments and different drying methods on color parameters and lycopene content of dried tomato. Bulgarian Journal of Agricultural Science, 17(6): 867-881.

Sanni, L. O., Babajide, J. M. and Ojerinde, M. W. (2007). Effect of chemical pretreatments on the physicochemical and sensory attributes of sweet potato-gari. ASSET International Journal. 6(1): 41-49.

Stanley, D. W., Bourne, M.C., Stone, A.P. and Wismer, W.V. (1995). Low temperature

\section{How to cite this article:}

Kapadiya, D.C., J.M. Makavana and Kathiria, M.K. 2018. Effect of Hot Water Blanching Treatment on Quality of Dried Potato Slices. Int.J.Curr.Microbiol.App.Sci. 7(07): 2754-2764. doi: https://doi.org/10.20546/ijcmas.2018.707.322 
Appendix A

\begin{tabular}{|c|c|c|c|c|c|c|c|}
\hline $\begin{array}{l}\text { Sr. } \\
\text { No. }\end{array}$ & Treatments & $\begin{array}{c}\text { Recovery of } \\
\text { dried potato } \\
\text { slices }(\%)\end{array}$ & $\begin{array}{c}\text { Shrinkage } \\
(\%)\end{array}$ & $\begin{array}{c}\text { Rehydration } \\
\text { ratio }\end{array}$ & $\begin{array}{c}\text { Reducing } \\
\text { sugar } \\
(\mathrm{mg} / \mathrm{g})\end{array}$ & $\begin{array}{c}\text { Sucrose } \\
(\mathrm{mg} / \mathrm{g})\end{array}$ & $\begin{array}{c}\text { Total } \\
\text { phenol } \\
(\mathrm{mg} / \mathrm{g})\end{array}$ \\
\hline $\mathbf{1}$ & $\mathrm{B} 1\left(\mathrm{~T}_{1} \mathrm{t}_{1}\right)$ & 23.20 & 35.61 & 17.43 & 11.13 & 7.49 & 1.31 \\
\hline $\mathbf{2}$ & $\mathrm{B} 2\left(\mathrm{~T}_{1} \mathrm{t}_{2}\right)$ & 19.82 & 29.78 & 17.62 & 9.46 & 6.87 & 1.25 \\
\hline $\mathbf{3}$ & $\mathrm{B} 3\left(\mathrm{~T}_{1} \mathrm{t}_{3}\right)$ & 20.00 & 27.90 & 15.49 & 5.42 & 5.76 & 1.18 \\
\hline $\mathbf{4}$ & $\mathrm{B} 4\left(\mathrm{~T}_{1} \mathrm{t}_{4}\right)$ & 20.18 & 31.35 & 17.44 & 3.04 & 3.59 & 0.95 \\
\hline $\mathbf{5}$ & $\mathrm{B} 5\left(\mathrm{~T}_{2} \mathrm{t}_{1}\right)$ & 24.18 & 39.67 & 17.25 & 11.21 & 7.46 & 1.58 \\
\hline $\mathbf{6}$ & $\mathrm{B} 6\left(\mathrm{~T}_{2} \mathrm{t}_{2}\right)$ & 18.92 & 32.07 & 16.03 & 9.76 & 8.01 & 1.45 \\
\hline $\mathbf{7}$ & $\mathrm{B} 7\left(\mathrm{~T}_{2} \mathrm{t}_{3}\right)$ & 23.44 & 41.76 & 15.91 & 7.11 & 6.44 & 1.20 \\
\hline $\mathbf{8}$ & $\mathrm{B} 8\left(\mathrm{~T}_{2} \mathrm{t}_{4}\right)$ & 22.60 & 36.79 & 16.65 & 4.23 & 5.23 & 0.99 \\
\hline $\mathbf{9}$ & $\mathrm{B} 9\left(\mathrm{~T}_{3} \mathrm{t}_{1}\right)$ & 20.18 & 36.07 & 16.55 & 10.64 & 6.97 & 1.45 \\
\hline $\mathbf{1 0}$ & $\mathrm{B} 10\left(\mathrm{~T}_{3} \mathrm{t}_{2}\right)$ & 21.00 & 32.50 & 15.92 & 8.90 & 7.23 & 1.38 \\
\hline $\mathbf{1 1}$ & $\mathrm{B} 11\left(\mathrm{~T}_{3} \mathrm{t}_{3}\right)$ & 22.00 & 48.57 & 16.44 & 4.99 & 6.12 & 1.19 \\
\hline $\mathbf{1 2}$ & $\mathrm{B} 12\left(\mathrm{~T}_{3} \mathrm{t}_{4}\right)$ & 21.00 & 40.86 & 16.91 & 2.91 & 3.76 & 0.98 \\
\hline $\mathbf{1 3}$ & $\mathrm{B} 13\left(\mathrm{~T}_{4} \mathrm{t}_{1}\right)$ & 22.58 & 35.80 & 16.33 & 10.09 & 6.88 & 1.10 \\
\hline $\mathbf{1 4}$ & $\mathrm{B} 14\left(\mathrm{~T}_{4} \mathrm{t}_{2}\right)$ & 20.60 & 33.66 & 15.31 & 8.41 & 5.28 & 0.99 \\
\hline $\mathbf{1 5}$ & $\mathrm{B} 15\left(\mathrm{~T}_{4} \mathrm{t}_{3}\right)$ & 17.87 & 36.23 & 19.13 & 4.98 & 4.79 & 0.96 \\
\hline $\mathbf{1 6}$ & $\mathrm{B} 16\left(\mathrm{~T}_{4} \mathrm{t}_{4}\right)$ & 17.35 & 50.50 & 17.15 & 2.28 & 3.45 & 0.92 \\
\hline $\mathbf{1 7}$ & $\mathrm{B} 17\left(\mathrm{~T}_{5} \mathrm{t}_{1}\right)$ & 19.74 & 45.57 & 17.51 & 10.26 & 6.78 & 1.00 \\
\hline $\mathbf{1 8}$ & $\mathrm{B} 18\left(\mathrm{~T}_{5} \mathrm{t}_{2}\right)$ & 20.80 & 41.58 & 16.84 & 8.04 & 5.47 & 0.91 \\
\hline $\mathbf{1 9}$ & $\mathrm{B} 19\left(\mathrm{~T}_{5} \mathrm{t}_{3}\right)$ & 22.05 & 61.41 & 16.94 & 4.69 & 4.26 & 0.89 \\
\hline $\mathbf{2 0}$ & $\mathrm{B} 20\left(\mathrm{~T}_{5} \mathrm{t}_{4}\right)$ & 21.92 & 52.17 & 16.77 & 1.80 & 2.91 & 0.85 \\
\hline $\mathbf{4}$ & & & & & & \\
\hline
\end{tabular}

Mean values of physical and biochemical parameters of dried potato slices 


\section{Appendix B}

\begin{tabular}{|c|c|c|c|c|c|c|}
\hline Sr.No. & Treatments & Colour & Odour & Taste & Texture & O.A. \\
\hline $\mathbf{1}$ & $\mathrm{B} 1\left(\mathrm{~T}_{1} \mathrm{t}_{1}\right)$ & 6 & 7 & 6 & 8 & 7 \\
\hline $\mathbf{2}$ & $\mathrm{B} 2\left(\mathrm{~T}_{1} \mathrm{t}_{2}\right)$ & 8 & 8 & 5 & 7 & 6 \\
\hline $\mathbf{3}$ & $\mathrm{B} 3\left(\mathrm{~T}_{1} \mathrm{t}_{3}\right)$ & 7 & 7 & 6 & 8 & 6 \\
\hline $\mathbf{4}$ & $\mathrm{B} 4\left(\mathrm{~T}_{1} \mathrm{t}_{4}\right)$ & 8 & 8 & 8 & 6 & 7 \\
\hline $\mathbf{5}$ & $\mathrm{B} 5\left(\mathrm{~T}_{2} \mathrm{t}_{1}\right)$ & 7 & 8 & 6 & 7 & 8 \\
\hline $\mathbf{6}$ & $\mathrm{B} 6\left(\mathrm{~T}_{2} \mathrm{t}_{2}\right)$ & 6 & 8 & 6 & 8 & 7 \\
\hline $\mathbf{7}$ & $\mathrm{B} 7\left(\mathrm{~T}_{2} \mathrm{t}_{3}\right)$ & 7 & 6 & 8 & 7 & 7 \\
\hline $\mathbf{8}$ & $\mathrm{B} 8\left(\mathrm{~T}_{2} \mathrm{t}_{4}\right)$ & 6 & 5 & 6 & 5 & 5 \\
\hline $\mathbf{9}$ & $\mathrm{B} 9\left(\mathrm{~T}_{3} \mathrm{t}_{1}\right)$ & 7 & 6 & 7 & 6 & 6 \\
\hline $\mathbf{1 0}$ & $\mathrm{B} 10\left(\mathrm{~T}_{3} \mathrm{t}_{2}\right)$ & 7 & 7 & 7 & 7 & 7 \\
\hline $\mathbf{1 1}$ & $\mathrm{B} 11\left(\mathrm{~T}_{3} \mathrm{t}_{3}\right)$ & 9 & 8 & 9 & 8 & 9 \\
\hline $\mathbf{1 2}$ & $\mathrm{B} 12\left(\mathrm{~T}_{3} \mathrm{t}_{4}\right)$ & 8 & 8 & 8 & 8 & 8 \\
\hline $\mathbf{1 3}$ & $\mathrm{B} 13\left(\mathrm{~T}_{4} \mathrm{t}_{1}\right)$ & 6 & 5 & 6 & 7 & 5 \\
\hline $\mathbf{1 4}$ & $\mathrm{B} 14\left(\mathrm{~T}_{4} \mathrm{t}_{2}\right)$ & 6 & 6 & 6 & 6 & 6 \\
\hline $\mathbf{1 5}$ & $\mathrm{B} 15\left(\mathrm{~T}_{4} \mathrm{t}_{3}\right)$ & 5 & 7 & 8 & 5 & 6 \\
\hline $\mathbf{1 6}$ & $\mathrm{B} 16\left(\mathrm{~T}_{4} \mathrm{t}_{4}\right)$ & 8 & 8 & 8 & 8 & 8 \\
\hline $\mathbf{1 7}$ & $\mathrm{B} 17\left(\mathrm{~T}_{5} \mathrm{t}_{1}\right)$ & 7 & 8 & 8 & 7 & 8 \\
\hline $\mathbf{1 8}$ & $\mathrm{B} 18\left(\mathrm{~T}_{5} \mathrm{t}_{2}\right)$ & 7 & 7 & 7 & 7 & 7 \\
\hline $\mathbf{1 9}$ & $\mathrm{B} 19\left(\mathrm{~T}_{5} \mathrm{t}_{3}\right)$ & 7 & 6 & 5 & 6 & 6 \\
\hline $\mathbf{2 0}$ & $\mathrm{B} 20\left(\mathrm{~T}_{5} \mathrm{t}_{4}\right)$ & 6 & 6 & 7 & 6 & 6 \\
\hline
\end{tabular}

Mean values of sensory characteristics dried potato slices 